\title{
Studies on the Relationship between Music Cultural Inheritance and College Music Education
}

\author{
Yu Fang \\ JingDeZhen University, JingDeZhen, China ,333000
}

Keywords: music culture; inheritance; colleges; music education

\begin{abstract}
The close relationship between music cultural inheritance and the development of college music education is that the music education would guarantee the social value and impetus to music culture. Based on the analyses on the connotations of music culture and education, this paper pointed out the correlation between music cultural inheritance and college music education to explore the development routes which includes reforming curriculum to have diversified education, improving music cultural ideology to arouse the enthusiasm of learning and optimizing the faculty to carry forward orthodox music culture.
\end{abstract}

\section{Connotations of music culture and music education}

In the long history of music culture, it promoted a more mature music education while gain vitality of existence and development from the education. It is essential to realize and understand the status and role of music education in inheriting and developing China's music culture due to their close relationship.

From the historical perspective, the development connotations of "culture" and "education" are closely linked. "Culture" in ancient ages referred to being well educated or artistic appreciated, while in the latest dictionary it refers to the groups that have created spiritual wealth in the fields of education, science and culture, "music" could be included in the category of culture.

What can be found from the inextricable links of the two is that music, while included by culture, embodies the spiritual connotation of culture. They are promoted and developed by each other.

The concept of music culture consists of a broad and a narrow level. The broad level, mainly refers to the cultures related with music activities acquired from everyday learning, contains the three levels of material, spiritual and institutional. The narrow level, relatively simple, contains only the music correlated activities that limited to the spiritual level and excludes the material and institutional levels.

The concept of music education, originated from German, included all teaching activities concerning music at first, was notably different from today's professional music teaching activities. With the popularization and development of music education, China has its own understanding on it.

The wild covered broad concept of music education contains all activities concerning music, mainly refers to those have unconscious influence. From the narrow level, music culture refers to those targeted music educational activities restricted to school.

It is therefore not difficult to realize the coexistence of distinguish and commonness between music culture and music education from the connotations of them. Music culture, covering part of music education, is not however, exactly the same as the latter. While music education, an essential condition for the formation of music culture, is not strictly the only requirement.

In understanding music cultural inheritance, the relationship between music education and the culture is significant and inescapable. Only by developing music education compatible with different aspects can music inheritance be realized from the view of connotation. Meanwhile, as an important component of music education, college music education is of significance and worth studying in inheriting music culture. 


\section{Correlation between music cultural inheritance and college music education}

\subsection{College music education is the important carrier inheriting music culture}

College music education, the disseminator and one form of music culture, highlights more social values and plays a vital role in inheriting culture. Broadening the developing routes of music culture, college music education is functioning in a more traditional way.

As a conscious and targeted instructional activity, college music education has become the most important way inheriting music culture in spreading more systemic and normative knowledge to the largest extent compared with other modes.

On the one hand, music related knowledge delivered by college music education own the characteristic of generality, and now occupies a key position in music cultural inheritance by helping learners experience the cultural communication in a natural course and then logically form a complete knowledge system.

On the other hand, college music education has become an indispensable tool inheriting music culture in using it as references to the best and carrying out deep reform to better promote its long-term development.

\subsection{College music education is the manifestation of music culture}

Music education, an important means and a significant manifestation inheriting music culture, can greatly improve the public music literacy and help them better appreciate its fascination.

For one thing, music education can be simply divided into three parts in the points of school: primary, elementary and advanced. Only in the advanced level, mostly refers to the college music education, can music culture really reflected and people's understanding to music up to the cultural level. From this point of view, college music education is the top priority in inheriting music culture.

Another notable thing is that when we include college music education in music culture the linkage between them are talked in the level of spiritual. In the view of college music education, it is actually associated with school music education by using it as a carrier to disseminate music culture extensively.

Therefore, as one of the manifestations of music culture, college music education bears significant responsibilities that directly affect the success of music cultural inheritance to a certain extent.

\subsection{Music culture is the important driving force of college music education development}

As a part of highest educational level, college education has its own flexibility. Though emphases to the music may differ, direct impact to the inheritance and development of music culture from college education either for music majors or for non-music majors cannot be denied. From this point of view, music culture is the driving force of college music education.

For one thing, while music culture can greatly improve the undergraduates' abilities in appreciating and feeling the beauty of Chinese folk music, it is the music education that leads them to understanding the richness of Chinese culture and to appreciating the enchantments of Chinese folk music in enriching their aesthetic experience.

The other thing is that college music education can greatly strengthen the confidence and senses of pride in undergraduates. Being an indispensable part of Chinese art, music culture invisibly improves people's moral sentiments and ideological level as well as their self-confidence and senses of great pride. Thus from this perspective, music culture is now playing an indispensable role never achieved by other means in promoting the development of China's college music education.

\section{The routes of music cultural inheritance in college music education development}

\subsection{Reforming curriculum to carry out diversified teaching}

This essay made analyses on the public elective courses on music in China's three relatively well-known universities (Peking University, Amoy University and Zhejiang Normal University) and found out the commonness in the curriculum setting.

Chart 1 public elective curriculum setting in China's three well-known universities 
School Course Course contents

History of Western music, Introduction to the history of Western music culture such as masterpiece appreciation Baroque and classic

Peking basic music theory, basic Introduction to basic music theories such as rhythm, beat and University knowledge of orchestra melody

Appreciation of Chinese and Appreciation of Chinese and Western masterpiece, history of Western masterpieces Chinese and Western music

Jazz music appreciation

Music appreciation

Appreciation of Chinese and Western masterpieces

Amoy

University

Appreciation of Country music

Appreciation of Western music

Appreciation of Symphony

Basic music theories

Zhejiang

Normal

University
Appreciation of Chinese music

Appreciation of Western music
Introduction to Jazz music in America and other Western countries

Introduction to music pieces of different times and styles like ethnic folk music

Excellent music pieces from China and foreign countries including China's national folk music

Introduction to American country music and rock music etc

Introduction to famous operas with different styles in different times and appreciation of modern musical

Introduction to excellent Chinese and Western symphonies in different times

Introduction to basic music theories such as rhythm, beat and melody

Introduction to China's excellent music pieces in different times

Introduction to Western excellent music pieces in different times

The single courses, mostly confined to the basic music theories and appreciation of Chinese and Western music etc, fail to pay due attention to Chinese music cultural knowledge, which only appears in the public elective courses as supplementary ones. 
As shown in Chart 1, courses of appreciating Chinese and Western masterpieces in Zhejiang Normal University are almost the same as the courses of appreciation of Chinese and Western music in Amoy University, all limited to the introduction to Chinese and Western music pieces with different styles in different times. Curriculums as these could never lead music education in a diversified development road.

Therefore, to have genuine music cultural inheritance, reform to the curriculum setting is unavoidable. On the one hand, courses that close to music culture rather than staying on the surface are needed. On the other hand, diversified researches on college music education are essential in broadening teaching ideas and running music teaching through every teaching stages rather than limited to public classes.

Only with these can music culture be conveyed to the educational practice of college students.

\subsection{Improving music cultural ideology to arouse learning enthusiasm}

The current situation in China's universities and colleges is that a number of undergraduates focus only on pop music while knowing little or even feeling distaste about China's traditional music culture.

Chart 2 Do you like China's national folk music?

\begin{tabular}{llll}
\hline Answers & like & Don't care & dislike \\
\hline The number of answerers & 138 & 231 & 118 \\
Proportion of the total & $28.3 \%$ & $47.4 \%$ & $24.3 \%$
\end{tabular}

Chart 3 Do you think is there anything to do with non-music majors in inheriting China's national folk music?

\begin{tabular}{llll}
\hline Answers & Yes & Not much & No \\
\hline The number of answerers & 12 & 87 & 388 \\
Proportion of the total & $2.4 \%$ & $17.9 \%$ & $79.9 \%$ \\
\hline
\end{tabular}

Take Chart 2 as an example, 487 effective questionnaires revealed that about $24.3 \%$ of students dislike China's national folk music culture while about $28.3 \%$ (138) think highly of it.

Meanwhile, concerning the question that "Do you think is there anything to do with non-music majors in inheriting China's national folk music?" about $79.9 \%$ of students answered "No", with only 12 "Yes", accounting $2.4 \%$.

Necessary measures are required for colleges and universities to optimize and improve the ideology of undergraduates in solving ideological problems. For one thing, pay attention to the popularization of music culture with propaganda in ordinary teaching activities to rectify the false thinking. The other thing is to arouse the undergraduates' enthusiasm to music culture at the greatest extent, leading them to change their attitudes towards music culture.

It could be said that only by changing students' understandings to music culture can it really be inherited and developed by stimulating students' initiative.

\subsection{Optimizing the faculty to promote orthodox music culture}

Strengthening the faculty construction counts a lot to music cultural inheritance since teachers, the subject of music education, are now a key component in inheriting music culture.

On the one hand, attention should be paid to improving college teachers' music accomplishments with strict appointments to recruit more professional music teachers as far as possible. Focusing on cultivating talents with comprehensive qualities, more developing space should give to teachers. Moreover, the professional abilities of teachers should be improved during the process of music teaching while reforms with the help of present resource superiority should be carried out to get improvements to the largest extent. 
On the other hand, strengthen the supervision on the teaching quality and have random inspection to ensure the effectiveness and practicability of music courses. Meanwhile, emphases should be laid to carrying forward orthodox music culture by integrating non-music majors into music cultural learning.

\section{References}

[1] Charles B. Hutchison. Cross - Cultural Issues Arising for Four Science Teachers During Their International Migration to Teach in U.S. High Schools[J]. School Science and Mathematics. 2010 (2)

[2] Ali Ozturk. Evaluation of the Teachers, Views on the Rhythm Practices in Musical Activities in Preschool Institutions. Social and Behavioral Sciences . 2010

[3] Folkestad G. Review Article on "Music, Informal Learning and the School: A New Classroom Pedagogy”' by Lucy Green. Music Education Research. 2008

[4] Russell-Bowie, Deirdre. Cross-National Comparisons of Background and Confidence in Visual Arts and Music Education of Pre-service Primary Teachers. . 2010

[5] Johnson, Vicky V. Competencies, Curricula, and Compliance: An Analysis of Music Theory in Music Education Programs in Texas. . 2010 